\title{
Moroccan oil shale and coal waste as alternative raw materials in Portland cement clinker manufacture. Clinkerisation reactions and clinker characterisation
}

\author{
S. Chhaiba ${ }^{\mathrm{a} b} \bowtie$, M.T. Blanco-Varela ${ }^{\mathrm{a}}$, A. Diouri ${ }^{\mathrm{b}}$ \\ a. Instituto de Ciencias de la Construcción Eduardo Torroja (IETcc-CSIC), (Madrid, Spain) \\ b. Laboratoire de Chimie du SolideAppliquée, Faculté des Sciences Université Mohammed V, (Rabat, Maroc) \\ $\triangle$ salmachhaiba@gmail.com
}

Received 30 June 2017

Accepted 28 February 2018

On line first 10 July 2018

\begin{abstract}
For some time the cement industry has been seeking procedures to effectively lower the higher energy costs involved in cement manufacture. Timahdit oil shale and Jerada coal waste could potentially be used as alternative raw materials to produce clinker. This study explored the possibility of applying those materials to a greener use, based on the reactivity and burnability of raw mixes containing Moroccan oil shale and coal waste. The findings showed that, irrespective of particle size, oil shale mixes delivered higher reactivity than coal waste materials, although reactivity was highest in the oil shale clinker with a particle size $<45 \mu \mathrm{m}$. The clinkers bearing oil shale with a particle size $<90 \mu \mathrm{m}$ or a blend of oil shale and coal waste with a size $<45 \mu \mathrm{m}$ contained higher proportions of alite $(>70 \%)$.
\end{abstract}

Keywords: Clinker manufacture; Raw mixes; Oil shale; Coal waste; Reactivity.

Citation/Citar como: Chhaiba, S.; Blanco-Varela, M.T.; Diouri, A. (2018) Moroccan oil shale and coal waste as alternative raw materials in Portland cement clinker manufacture. Clinkerisation reactions and clinker characterisation. Mater. Construcc. 68 [331], e166 https://doi.org/10.3989/mc.2018.07017

RESUMEN: Esquistos bituminosos como materia prima alternative en la fabricación de clínker de cemento Portland. Reacciones de clinkerización y caracterización del clínker. La industria cementerabusca desde hace algún tiempo procedimientos que reduzcan el alto consumo de energía de la producción de cemento. La pizarra bituminosa de Timahdit (BOS) y los desechos de carbón de Jerada (CW) se pueden utilizar potencialmente como materiales alternativos en la fabricación de clinker. Este estudio se enfoca en evaluar esta posibilidad, valorizar dichos materiales y considerar un uso más ecológico para ellos. Exploramos la reactividad y la aptitud a la cocción de mezclas crudas de clínker que contienen BOS o CW. La reactividad de los crudos que contienen BOS es mejor que la de los que contienen CW, independientemente de su tamaño de partícula, siendo el que contiene BOS con un tamaño de partícula $<45 \mu \mathrm{m}$, la más reactiva. Los clínkeres que contienen BOS o la mezcla de BOS y CW (tamaño de partícula $<90 \mu \mathrm{m}$ y $45 \mu \mathrm{m}$ respectivamente) contienen proporciones de alita $>70 \%$.

Palabras clave: Fabricación de cemento; Mezclas crudas; Esquisto bituminoso; Residuo de carbón; Reactividad.

ORCID ID: S. Chhaiba (http://orcid.org/0000-0003-0856-1358); M.T. Blanco-Varela (http://orcid.org/0000-0003-33063289); A. Diouri (http://orcid.org/0000-0002-4590-1262)

Copyright: (C) 2018 CSIC. This is an open-access article distributed under the terms of the Creative Commons Attribution 4.0 International (CC BY 4.0) License 


\section{INTRODUCTION}

Cement, in many ways an essential material, is used world wideas a concrete component. Portland cement is made primarily from finely ground clinker, which itself is composed of calcium silicate and aluminate minerals formed when limestone and other materials are burnt at high temperatures. The cement industry is believed to account for over $8 \%$ of worldwide $\mathrm{CO}_{2}$ emissions (1). Further to the conclusions of a number of international conferences (Kyoto, The Hague, Copenhagen)(2), the pursuit of 'sustainability' is a must to striking a balance between technological and environmental development. The scientific and industrial communities are consequently in constant pursuit of ways to manufacture cement more energy- and eco-efficiently. One avenue toward that goal is to valorise and reuse industrial waste as alternative raw materials in cement manufacture (3), a practice that would also reduce natural resource consumption.

Oil shale is one of humanity's most promising sources of energy and chemicals (4) and Morocco has one of the world's largest oil shale reserves (5). Moreover, the Jerada coal mine in the country's northeast generates large amounts of waste (6-8), with the recoverable total estimated at 134.482 (short) Gt.Valorising that waste would reduce stockpiling, solving urban planning problems and mitigating the environmental impact of pyrite oxidation in the waste (9).

Recent research (10 - 11) has shown that Moroccan oil shale and coal waste are chemically and mineralogically apt for inclusion in raw cement mixes.

The present study aimed to determine the reactivity and burnability of portland cement raw mixes in which conventional raw materials were replaced with Timahdit oil shale and Jerada coal waste.

\section{MATERIALS AND METHODS}

The materials used in this study were collected from the Timahdit shale bed, characterised by four lithological zones (T, Y, X and M), and the coal waste $(\mathrm{CW})$ stockpiled at Jerada. The four layers of Timahdit oil shale were mixed to a homogeneous blend (BOS). BOS and $\mathrm{CW}$ were each sieved to three particle sizes:

- $\mathrm{BOS}<45 \mu \mathrm{m}$,

- $90 \mu \mathrm{m}>$ BOS $>45 \mu \mathrm{m}$,

- $125 \mu \mathrm{m}>\mathrm{BOS}>90 \mu \mathrm{m}$,

- $\mathrm{CW}<45 \mu \mathrm{m}$,

- $90 \mu \mathrm{m}>\mathrm{CW}>45 \mu \mathrm{m}$,

- $125 \mu \mathrm{m}>\mathrm{CW}>90 \mu \mathrm{m}$

The mean chemical composition for each fraction of BOS and CW is given in Table 1. Loss on ignition (LoI), determined by heating $5 \mathrm{~g}$ of sample at $1000^{\circ} \mathrm{C}$ in a laboratory muffle furnace, is expressed in the table as $\mathrm{wt} \%$ of the starting material. Spanish limestone was ground to under $125 \mu \mathrm{m}$ for the raw mixes, which were corrected for iron content with $96 \%$ pure ferric oxide.

The reactivity and burnability of raw mixes prepared with BOS, CW, limestone and laboratory grade $\mathrm{Fe}_{2} \mathrm{O}_{3}$ were compared to assess the viability of using oil shale and coal waste as raw materials in portland clinker. Their composition is given in Table 2.

Raw mix reactivity was determined in an air atmosphere with DSC/TG/DTG and burnability by measuring the free lime in the mixes after burning at $1400{ }^{\circ} \mathrm{C}$ for $30 \mathrm{~min}$ and applying Fundal's (12) empirical equation:

$\% \mathrm{CaO}_{\text {(free) }}=0.31(\mathrm{LSF}-100)+2.18\left(\mathrm{M}_{\mathrm{S}}-18\right)+$ $0.73 \mathrm{Q}_{45}+0.33 \mathrm{C}_{125}+0.34 \mathrm{Aq}$

Where LSF $\left(=\mathrm{CaO} /\left(2.8 \mathrm{SiO}_{2}+1.18 \mathrm{Al}_{2} \mathrm{O}_{3}+0.65\right.\right.$ $\left.\mathrm{Fe}_{2} \mathrm{O}_{3}\right)$ is the lime saturation factor, $\mathrm{M}_{\mathrm{S}}\left(=\mathrm{SiO}_{2} /\right.$ $\left(\mathrm{Al}_{2} \mathrm{O}_{3}+\mathrm{Fe}_{2} \mathrm{O}_{3}\right)$ the silica modulus, $\mathrm{Q}_{45}$ the fraction by weight of quartz particles $>45 \mu \mathrm{m}, \mathrm{C}_{125}$ the fraction by weight of limestone particles $>125 \mu \mathrm{m}$ and Aq the fraction of clay materials $>63 \mu \mathrm{m}$.

The raw mixes were prepared as follows.

After blending in a turbula for $60 \mathrm{~min}$, the raw materials were pelletised, set into platinum crucibles, clinkerised at $1400{ }^{\circ} \mathrm{C}$ for $30 \mathrm{~min}$ in a laboratory furnace, cooled at ambient temperature, ground and then sieved to under $45 \mu \mathrm{m}$. The free

TABLE 1. Chemical analysis (wt \%) of blended oil shale and coal waste by particle size

\begin{tabular}{lcccccccccc}
\hline Oxide & $\mathbf{C a O}$ & $\mathbf{A l}_{\mathbf{2}} \mathbf{O}_{\mathbf{3}}$ & $\mathbf{S i O}_{2}$ & $\mathbf{F e}_{\mathbf{2}} \mathbf{O}_{\mathbf{3}}$ & $\mathbf{S O}_{3}$ & $\mathbf{M g O}$ & $\mathbf{K}_{\mathbf{2}} \mathbf{O}$ & $\mathbf{M n O}$ & $\mathbf{P}_{\mathbf{2}} \mathbf{O}_{\mathbf{5}}$ & $\mathbf{L O I}$ \\
\hline $\mathbf{B O S}<\mathbf{4 5} \boldsymbol{\mu \mathbf { m }}$ & 19.37 & 8.52 & 23.94 & 2.56 & 3.59 & 2.1 & 1.06 & 0.01 & 0.25 & 37.67 \\
$\mathbf{9 0}>\mathbf{B O S}>\mathbf{4 5} \boldsymbol{\mu \mathbf { m }}$ & 16.45 & 10.44 & 28.89 & 2.87 & 3.56 & 1.73 & 1.16 & 0.01 & 1.01 & 33.26 \\
$\mathbf{1 2 5}>\mathbf{B O S}>\mathbf{9 0} \boldsymbol{\mu \mathbf { m }}$ & 15.41 & 9.78 & 27.05 & 2.69 & 3.32 & 1.62 & 1.07 & 0.01 & 0.94 & 37.48 \\
$\mathbf{C W}<\mathbf{4 5} \boldsymbol{\mu \mathbf { m }}$ & 0.57 & 21.63 & 52.03 & 4.65 & 0.91 & 0.99 & 2.97 & 0.06 & 0.07 & 14.26 \\
$\mathbf{9 0}>\mathbf{C W}>\mathbf{4 5} \boldsymbol{\mu \mathbf { m }}$ & 0.45 & 22.6 & 51.29 & 4.87 & 0.85 & 1.08 & 3.13 & 0.09 & 0.09 & 13.85 \\
$\mathbf{1 2 5}>\mathbf{C W}>\mathbf{9 0} \boldsymbol{\mu \mathbf { m }}$ & 0.66 & 20.54 & 53.22 & 4.47 & 1.16 & 0.89 & 2.76 & 0.08 & 0.08 & 14.54 \\
Limestone $<\mathbf{1 2 5} \boldsymbol{\mu m}$ & 47.21 & 2.75 & 5.26 & 0.91 & 0.05 & 0.98 & 0.46 & 0.01 & 0.01 & 40.98 \\
\hline
\end{tabular}


TABLE 2. Raw mix composition

\begin{tabular}{|c|c|c|c|c|}
\hline & \multicolumn{4}{|c|}{ Proportion (wt $\%)$} \\
\hline & Limestone & BOS & CW & $\mathrm{Fe}_{2} \mathrm{O}_{3}$ \\
\hline RM-BOS $<45 \mu \mathrm{m}$ & 66 & 33 & - & 1 \\
\hline $\mathrm{RM}-45 \mu \mathrm{m}<\mathrm{BOS}<90 \mu \mathrm{m}$ & 72.5 & 26.51 & - & 1 \\
\hline RM-90 $\mu \mathrm{m}<$ BOS $<125 \mu \mathrm{m}$ & 70.2 & 28.8 & - & 1 \\
\hline $\mathrm{RM}-\mathrm{CW} \mu \mathrm{m}<45 \mu \mathrm{m}$ & 83.06 & 15.54 & - & 1.4 \\
\hline $\mathrm{RM}-45 \mu \mathrm{m}<\mathrm{CW}<90 \mu \mathrm{m}$ & 85 & 14 & - & 1 \\
\hline RM-90 $\mu \mathrm{m}<\mathrm{CW}<125 \mu \mathrm{m}$ & 85 & 13.8 & - & 1.2 \\
\hline RM-BOS + CW $<45 \mu \mathrm{m}$ & 64.71 & 20.44 & 13.71 & 1.14 \\
\hline
\end{tabular}

lime content in the clinkers was found with the ethylene glycol method as specified in Spanish standard UNE 80243: 2014 (13). Mineralogical composition was determined by XRD and FTIR and clinker morphology was analysed under an optical microscope, whilst the phases were identified with SEM/EDX.

\section{Analytical techniques}

The majority elements in the raw materials were identified on a Philips PW1404 X-ray fluorescence spectrometer (XRF) operating at $40 \mathrm{kV}$ and $70 \mathrm{~mA}$ and fitted with a Sc-Mo tube, Super-Q software and four analyser crystals: PX-1, GE, LIF200, and LIF220. Differential scanning calorimetry (DSC) and thermogravimetric (DTA/TG) analysiswere simultaneously applied to $30 \mathrm{mg}$ samples using a SDTQ600 analyser. The heating rate was $10^{\circ} \mathrm{C} / \mathrm{min}$, the range $25^{\circ} \mathrm{C}$ to $1450{ }^{\circ} \mathrm{C}$ and the carrier gas $\mathrm{CO}_{2}$-free dry air, flowing at $100 \mathrm{~mL} / \mathrm{min}$.

For the morphological study clinker samples were encapsulated in epoxy resin, cut and polished and the surfaces etched with a solution of $\mathrm{HNO}_{3}$ in absolute ethanol for observation under a Nikon Eclipse ME600 reflected light microscope. Infrared spectra were recorded for $\mathrm{KBr}$ pellets at frequencies of $4000 \mathrm{~cm}^{-1}$ to $400 \mathrm{~cm}^{-1}$ on a Thermo Scientific Nicolet 600 FTIR spectrometer featuring a spectral resolution of $4 \mathrm{~cm}^{-1}$.

Clinker samples were polished and carbon coated for analysis on a JEOL JSM 6400 scanning electron microscope (SEM) operating at $20 \mathrm{keV}$.

Clinker mineralogy was characterised on a Bruker D8 Advance X-ray diffractometer fitted with a high voltage, $3 \mathrm{~kW}$ generator and a $(1.54-\AA$ $\mathrm{Cu} \mathrm{Ka}$ ) copper anode X-ray tube operating at 40 $\mathrm{kV}$ and $30 \mathrm{~mA}$, using the following settings: divergence slit, $6 \mathrm{~mm}$, variable; step time, $0.5 \mathrm{~s}$; step size, $0.019746^{\circ}$; scan time, $23^{\prime} 47^{\prime \prime} ; 2 \theta$ angle range, $5^{\circ}$ to $60^{\circ}$. Rietveld refinement was used to quantify the crystalline phases identified by XRD.

\section{RESULTS AND DISCUSSION}

Raw mix reactivity is defined in terms of the rate at which the reaction reaches completion at a given temperature. The reactions taking place during clinkerisation include thermal decomposition of the raw mix components, limestone in particular, solid state reactions between the acid and basic components to yield $\mathrm{C}_{3} \mathrm{~A}$ and $\mathrm{C}_{2} \mathrm{~S}$ and smaller proportions of $\mathrm{C}_{4} \mathrm{AF}$ and the formation of large amounts of $\mathrm{C}_{3} \mathrm{~S}$ in the presence of the eutectic liquid $(14,21)$.

\subsection{Thermal behaviour}

The DSC/TG curves for the raw mixes reproduced in Figures 1,2 and 3 show the temperatures and signal intensities used to compare the reactivity of the raw mixes. All the raw mixes containing BOS, irrespective of particle size, exhibited exothermal signals at $320{ }^{\circ} \mathrm{C}$ and $440{ }^{\circ} \mathrm{C}$, attributed to organic matter combustion. The curves for the mixes bearing $\mathrm{CW}$ (Figure 2) had an exothermal signal at around $580^{\circ} \mathrm{C}$, whilst three exothermal peaks were observed for the mix containing both BOS and CW, associated with the combustion of the organic matter in shale oil and coal waste (Figure 3). All the mixes exhibited an endothermal signal at about $800^{\circ} \mathrm{C}$, generated by the thermal decomposition of $\mathrm{CaCO}_{3}$, which began at around $550{ }^{\circ} \mathrm{C}$ and intensified at about $780^{\circ} \mathrm{C}$. The TG and DSC curves for both BOS and CW also showed that the smaller the particle size, the lower the temperature at which limestone decomposition began (Figure 1), inferring that raw mix reactivity was high in that temperature range.

The very low intensity exothermal signals observed for the BOS mixes between $1130{ }^{\circ} \mathrm{C}$ and $1279^{\circ} \mathrm{C}$, the $\mathrm{CW}$ mixes between $1260^{\circ} \mathrm{C}$ and $1295^{\circ} \mathrm{C}$ and the blended raw mix at $1130^{\circ} \mathrm{C}$ were all attributed to solid state reactions and the concomitant formation of $\mathrm{C}_{2} \mathrm{~S}$ (belite), $\mathrm{C}_{12} \mathrm{~A}_{7}, \mathrm{C}_{4} \mathrm{AF}(\mathrm{FF}), \mathrm{C}_{3} \mathrm{~A}$ (15-16) and $\mathrm{C}_{3} \mathrm{~S}$ at temperatures of over $1250{ }^{\circ} \mathrm{C}$. The signals appearing at lower temperatures suggested a slightly higher reactivity (17), particularly in the raw mixes consisting of particles $<45 \mu \mathrm{m}$ $\left(1130{ }^{\circ} \mathrm{C}\right)$ and $<90 \mu \mathrm{m}\left(1194{ }^{\circ} \mathrm{C}\right)$. In contrast, the exothermal solid state reaction was recorded at higher temperatures $\left(1253{ }^{\circ} \mathrm{C},<45 \mu \mathrm{m}\right.$ and 1262 ${ }^{\circ} \mathrm{C},<90 \mu \mathrm{m}$ ) in the $\mathrm{CW}$-bearing raw mixes, possibly denoting lower reactivity. The endothermal effect observed at $>1300^{\circ} \mathrm{C}$ in all the raw mixes denoted the formation of the molten mass in the clinkers. BOS and CW particle size affected the intensity of that signal, which appeared at lower temperatures in all the raw mixes with a particle size of $<45 \mu \mathrm{m}$, confirming their slightly higher reactivity. 

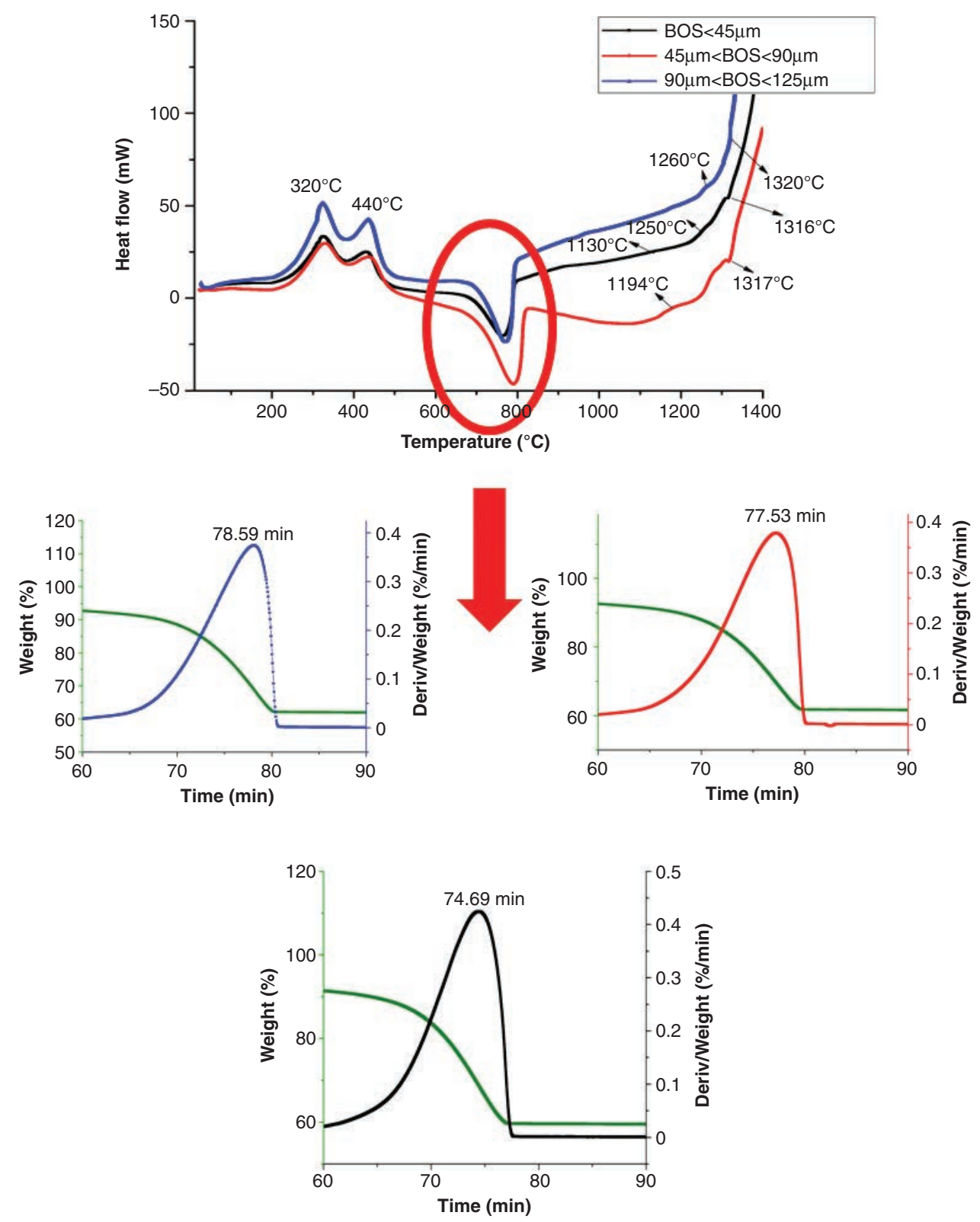

FIGURE 1. DSC/TG heat curves for BOS-containing raw mixes.

\subsection{Chemical composition}

Table 3 gives the chemical analysis for clinkers burnt at $1400{ }^{\circ} \mathrm{C}$ and ground and sieved to $<45 \mu \mathrm{m}$ or $90 \mu \mathrm{m}<(\mathrm{BOS}, \mathrm{CW}$ or $\mathrm{BOS}+\mathrm{CW})<45 \mu \mathrm{m}$. The oxide content of the main constituents was similar in all the clinkers with the exception of $\mathrm{CW}<45 \mu \mathrm{m}$, which had a higher percentage of $\mathrm{SiO}_{2}$.

\subsection{X-ray diffraction analysis}

The diffractograms for the clinkers reproduced in Figures 4, 5 and 6 exhibited four major phases. The most visible difference revolved around the presence of free lime, intense lines for which appeared at $2 \theta=54^{\circ}$ and $2 \theta=37^{\circ}$ in $125 \mu \mathrm{m}>\mathrm{CW}>90 \mu \mathrm{m}$, but which were not detected in the other materials. The signal for the aluminate phase, in turn, was more intense in the CW than in the other clinkers. The Rietveld quantification of the clinker phases identified by XRD, normalising the crystalline phases to $100 \%$, was compared to the Bogue calculations for four clinker samples. Further to the data in Table 4, the BOS-bearing clinkers had a very high alite $\left(\mathrm{C}_{3} \mathrm{~S}: 3 \mathrm{CaO} \cdot \mathrm{SiO}_{2}\right)$ content, which was $15 \%$ greater experimentally than calculated from the Bogue formulas, whereas the $\mathrm{C}_{3} \mathrm{~A}\left(3 \mathrm{CaO} \cdot \mathrm{Al}_{2} \mathrm{O}_{3}\right)$ content found from the XRD patterns was much lower than found with the Bogue equations.

The explanation lies in that with Bogue, $\mathrm{C}_{3} \mathrm{~A}$ is calculated from the total $\mathrm{Al}_{2} \mathrm{O}_{3}$ as found with XRF, 
assuming that all the $\mathrm{Al}$ present is in the form of $\mathrm{C}_{3} \mathrm{~A}$ and the ferritic phase. In other words, the Bogue calculation fails to consider any $\mathrm{Al}$ which may be in the silicon positions in alite and belite. Furthermore, when cooling takes place slowly, $\mathrm{C}_{3} \mathrm{~A}$ crystallises more effectively from the molten mass and the resulting ferrite contains less $\mathrm{Al}$ in its structure, whilst when the cooling rate is faster, less microcrystalline $\mathrm{C}_{3} \mathrm{~A}$ forms and the ferrite phase has a higher $\mathrm{Al}$ content. Low clinker crystallinity may also be the reason for these differences, for in that case $\mathrm{Al}$ would be in vitreous or poorly crystallised interstitial phases. As in Rietveld analysis the
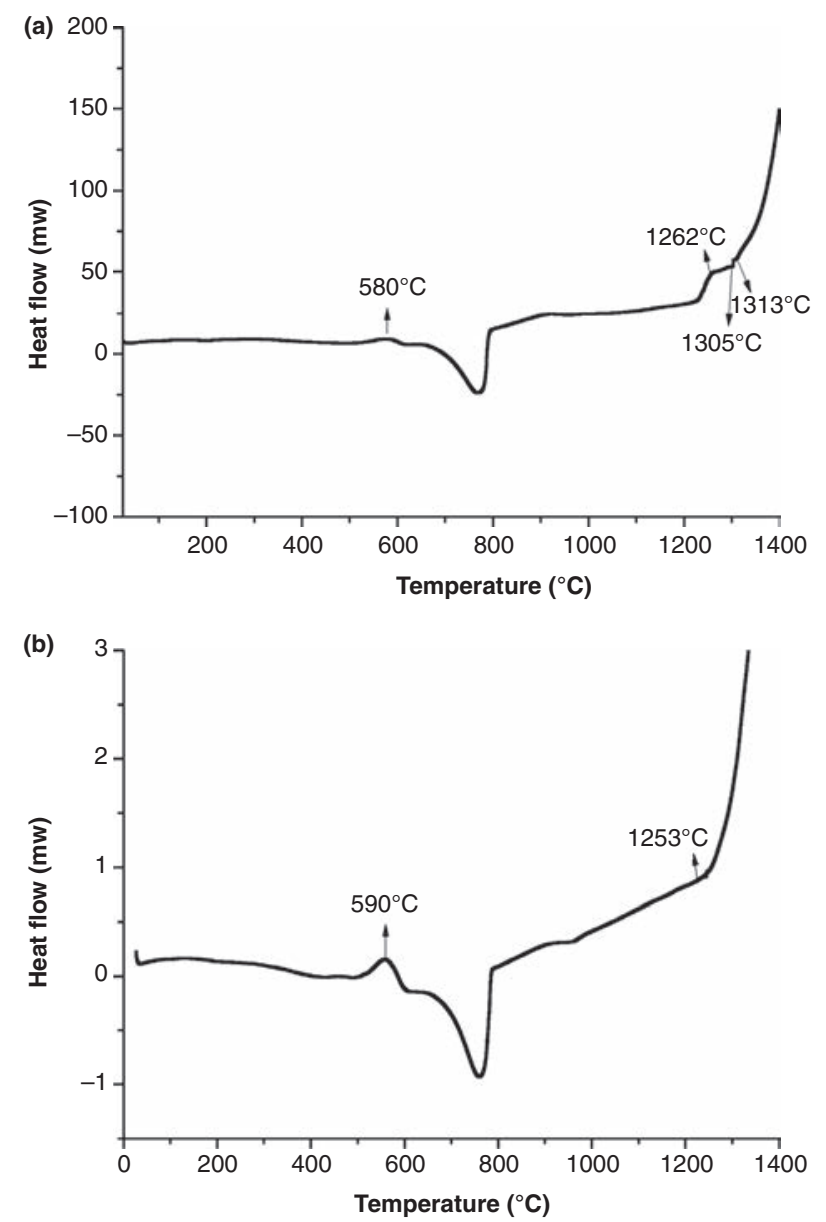

FIGURE 2. DSC/TG heat curves for CW-containing raw mixes.
XRD values are normalised to the total crystalline phase content and vitreous or poorly crystallised phases (which fail to crystallise during cooling) are disregarded, the silicate phases would be over estimated. The present findings showed that whilst the alumina content was much lower than found with Bogue, the difference for the ferritic phase was much narrower, suggesting that the BOS clinkers cooled quickly.

The CW clinker with particles $<45 \mu \mathrm{m}$ had a lower proportion of $\mathrm{C}_{3} \mathrm{~S}$ than the BOS-containing clinkers, whilst its belite content was higher. This clinker had a higher Rietveld-determined $\mathrm{C}_{3} \mathrm{~A}$ than ferrite content, although both were lower than the values found with the Bogue formula.

\subsection{Fourier transform infrared spectroscopy}

The FTIR spectra for the clinkers reproduced in Figures 7, 8 and 9exhibited two distinct signals, one at around $3436 \mathrm{~cm}^{-1}$ attributed to $\mathrm{OH}$ stretching vibrations and the other at $1633 \mathrm{~cm}^{-1}$ to $\mathrm{H}-\mathrm{O}-\mathrm{H}$ bending vibrations, both in water. The most intense band, centred in the Si-O stretching vibration zone at $924 \mathrm{~cm}^{-1}$, had two shoulders, at $890 \mathrm{~cm}^{-1}$ associated with alite and $841 \mathrm{~cm}^{-1}$ with belite. The signals at $725 \mathrm{~cm}^{-1}$ and $457 \mathrm{~cm}^{-1}$ were generated by the $\mathrm{Al}-\mathrm{O}$ vibrations in ferrite and tricalcium aluminate, respectively, whilst the signal at $520 \mathrm{~cm}^{-1}$ was attributable to both calcium silicates.

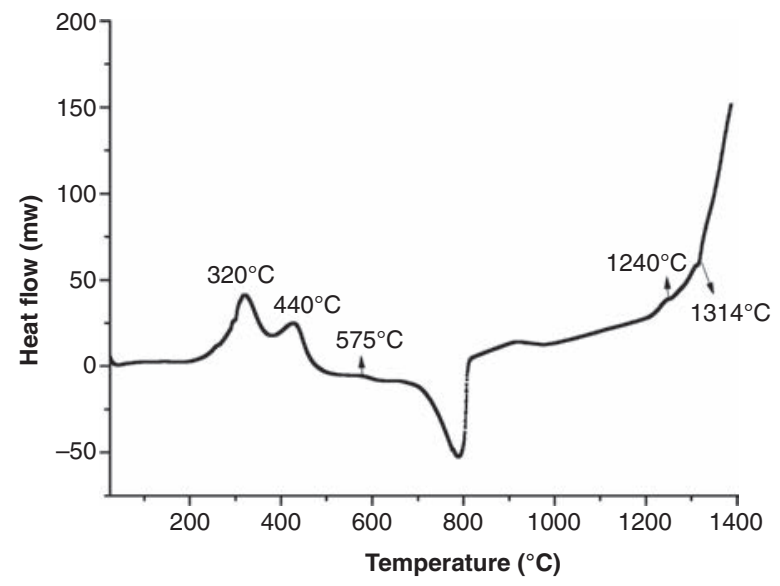

FIGURE 3. DSC/TG heat curves for BOS+CW-containing raw mixes.

TABLE 3. Chemical analysis of clinkers with particle size $<45 \mu \mathrm{m}$, expressed in oxides ( $\mathrm{wt} \%$ )

\begin{tabular}{lccccccccc}
\hline Oxide & $\mathbf{C a O}$ & $\mathbf{A l}_{\mathbf{2}} \mathbf{O}_{\mathbf{3}}$ & $\mathbf{S i O}_{2}$ & $\mathbf{F e}_{2} \mathbf{O}_{3}$ & $\mathbf{S O}_{3}$ & $\mathbf{M g O}$ & $\mathbf{K}_{2} \mathbf{O}$ & $\mathbf{Z n O}$ & $\mathbf{P}_{2} \mathbf{O}_{\mathbf{5}}$ \\
\hline $\mathbf{B O S}<\mathbf{4 5} \boldsymbol{\mu m}$ & 62.43 & 7.1 & 18.69 & 4.25 & 1.58 & 2.15 & 0.72 & 0.03 & 0.58 \\
$\mathbf{9 0}>\mathbf{B O S}>\mathbf{4 5} \boldsymbol{\mu m}$ & 63.96 & 6.12 & 18.72 & 3.77 & 1.29 & 1.79 & 0.65 & 0.02 & 0.47 \\
$\mathbf{C W}<\mathbf{4 5} \boldsymbol{\mu m}$ & 62.41 & 7.95 & 20.38 & 4.14 & 0.06 & 0.97 & 1.02 & 0.01 & 0.05 \\
$\mathbf{B O S}+\mathbf{C W}<\mathbf{4 5} \boldsymbol{\mu m}$ & 63.22 & 7.04 & 18.61 & 4.12 & 1.42 & 1.87 & 0.87 & 0.02 & 0.44 \\
\hline
\end{tabular}




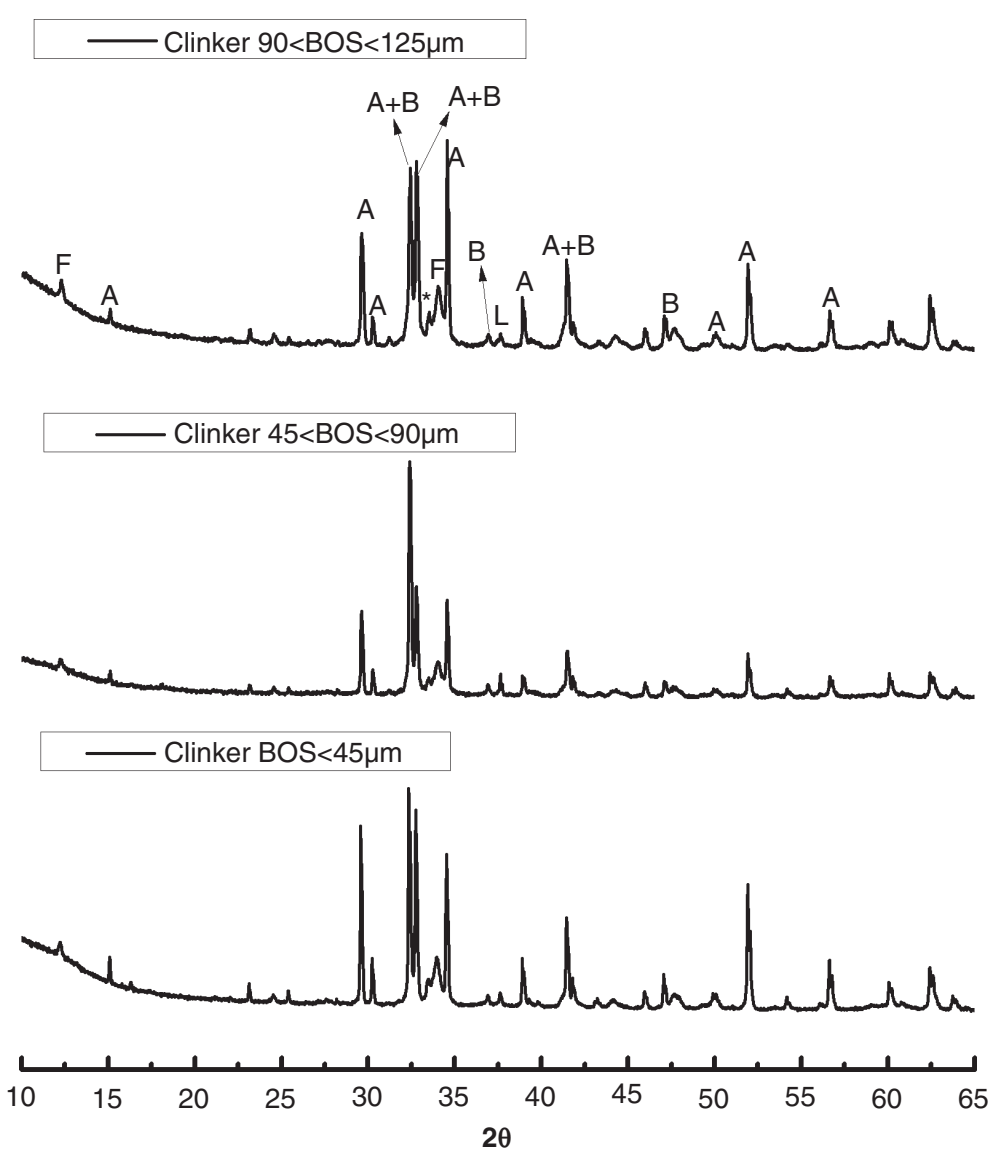

FIGURE 4. XRD patterns for BOS clinkers burnt at $1400^{\circ} \mathrm{C}$.

\subsection{Scanning electron microscopy / EDX}

The SEM micrographs of the clinkers reproduced in Figure 10 were the ones most representative of crystalline phase distribution that was very homogeneous. Well-formed alite crystals and small roundish belite particles were uniformly distributed, denoting rapid cooling. The fine interstitial material had a generally adequate crystalline structure with aluminate crystals interspersed in-between ferrite crystals.

EDX analysis identified the majority and minority elements in the phases in the micrographed regions of the clinker. According to the findings in Table 5, the phases in clinker CW had a higher percentage of $\mathrm{K}$ than the phases in the BOS material which, conversely, contained a higher percentage of $\mathrm{Mg}$. In other words, $\mathrm{Mg}$ was more soluble in the interstitial phase of the BOS-bearing clinker, whilst the belite in the clinker with both BOS and CW solubilised more K. Similarly, the belite in the BOS clinkers solubilised more Al, which may explain the lower percentage of $\mathrm{C}_{3} \mathrm{~A}$ in the Rietveld quantification than in the Bogue calculation. Majority and minority element solubility in the phases of a clinker depends not only on the chemical composition of the raw mix, but also on the cooling rate. The $\mathrm{Al}_{2} \mathrm{O}_{3} / \mathrm{Fe}_{2} \mathrm{O}_{3}$ ratio (or alumina modulus) was higher in the interstitial phases of $\mathrm{BOS}<45 \mu \mathrm{m}$ (1.07), $\mathrm{BOS}+\mathrm{CW}<45 \mu \mathrm{m}(1.11)$ and $\mathrm{CW}<45 \mu \mathrm{m}(1.03)$ than in the chemical composition of BOS $<45 \mu \mathrm{m}$ (1.7), BOS $+\mathrm{CW}<45 \mu \mathrm{m}$ (1.7) and $\mathrm{CW}<45 \mu \mathrm{m}$ (1.9). Those differences confirmed that not all the aluminium remained in the interstitial phase, but was also present in silicon positions in alite and belite.

\subsection{Reflected light optical microscopy}

The optical micrographs of resin-set, polished thin sections of clinker are shown in Figure 11. The alite phase in the BOS clinker $<45 \mu \mathrm{m}$ was highly crystallised and surrounded by an interstitial phase with some belite (Figure 11(a)). Phase distribution was uniform in the clinker containing $\mathrm{CW}$ (Figure 11(b)), which had a higher belite phase content as a result of insufficient raw mix homogenisation. These findings corroborate the lower reactivity of the CW mixes detected by other techniques.

Further to the micrographs of the BOS clinker with particle sizes $45 \mu \mathrm{m}$ to $90 \mu \mathrm{m}$ in Figure 11(c), alite crystals were distributed more heterogeneously and dispersed in the interstitial phase, whereas the 

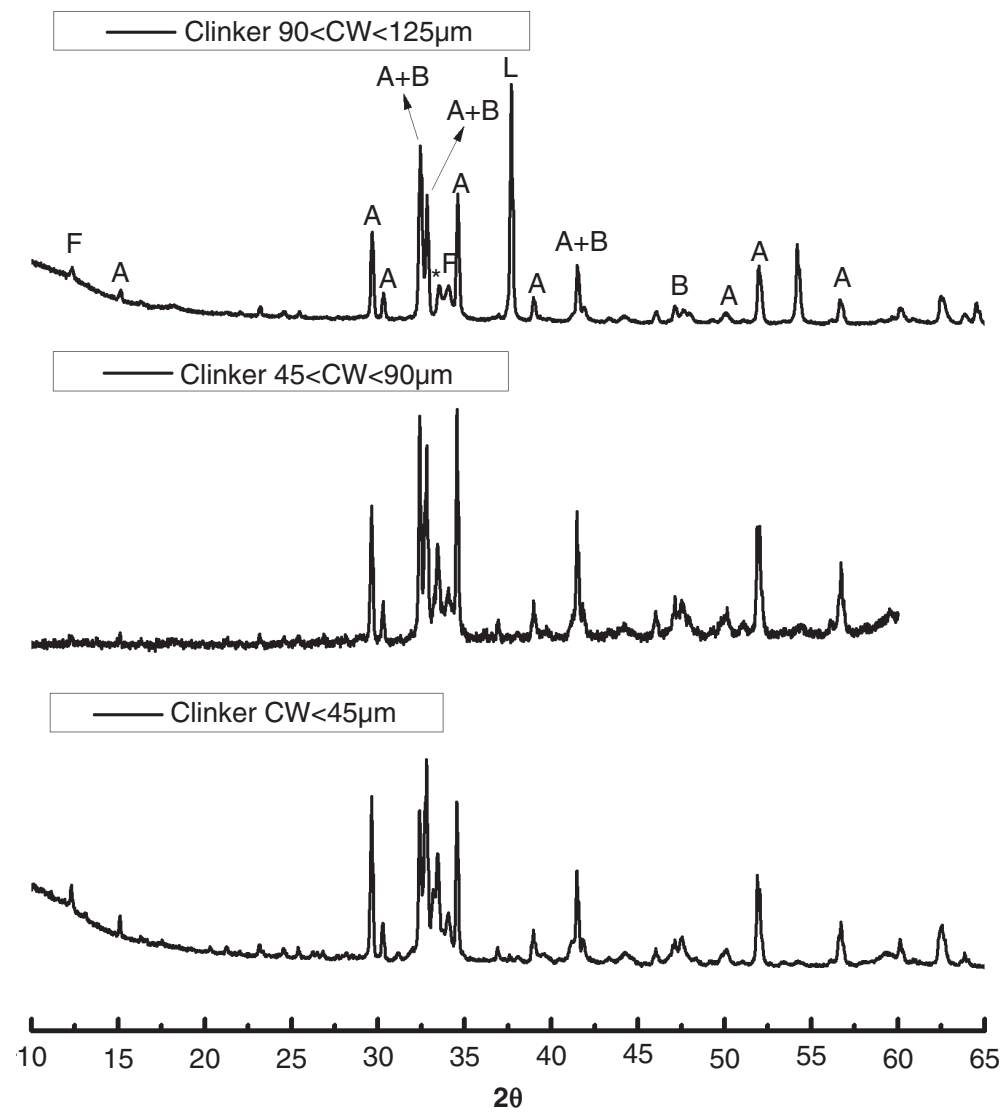

Figure 5. XRD patterns for $\mathrm{CW}$ clinkers burnt at $1400{ }^{\circ} \mathrm{C}$.

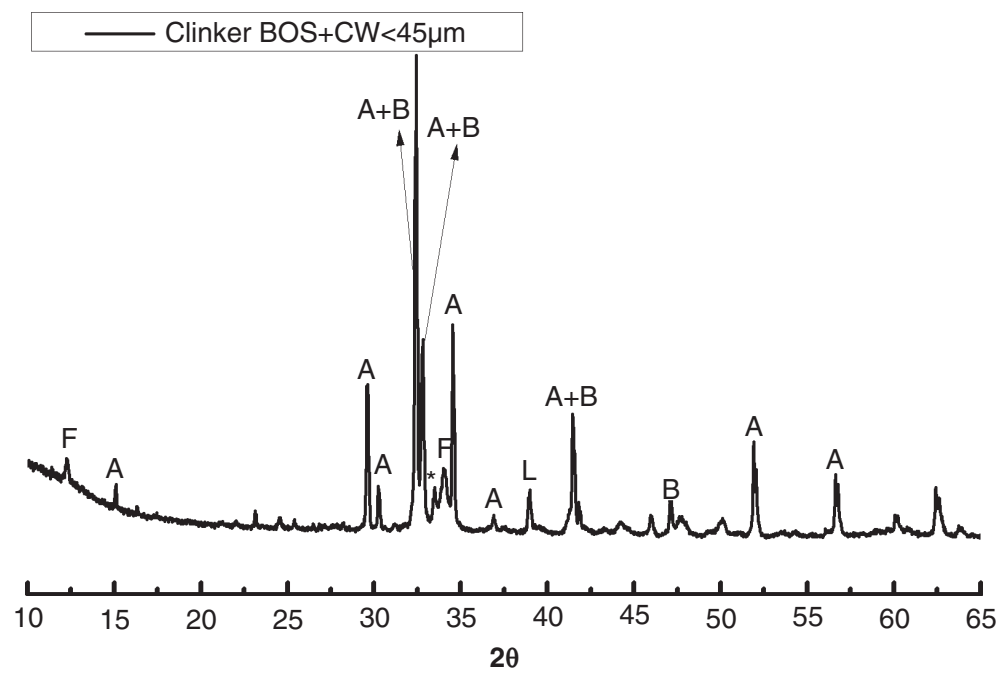

FIGURE 6. XRD patterns for BOS $+\mathrm{CW}$ clinkers burnt at $1400^{\circ} \mathrm{C}$.

belite content was low. A cluster of free lime was also detected in this clinker, in keeping with its high lime saturation factor (LSF) and the scant homogenisation of the raw mix. The clinker containing both BOS and CW also exhibited a heterogeneous phase distribution due to the presence of the low reactivity coal waste (Figure 11(d)). The alite particles present in the $\mathrm{CW}$ clinker were smaller than in the other materials. Whilst belite clusters were observed in all the clinkers, they were more abundant in the CW material, where the high belite content confirmed the Rietveld quantification findings. The microscopic study also corroborated the lower $\mathrm{C}_{3} \mathrm{~A}$ content found with the Rietveld method. 
TABLE 4. Quantitative analysis of the phases in clinkers (wt $\%$ )

\begin{tabular}{|c|c|c|c|c|c|c|c|c|}
\hline \multirow[b]{2}{*}{ Phase } & \multicolumn{2}{|c|}{ BOS $<45 \mu \mathrm{m}$} & \multicolumn{2}{|c|}{$\mathrm{CW}<45 \mu \mathrm{m}$} & \multicolumn{2}{|c|}{$\mathrm{BOS}+\mathrm{CW}<45 \mu \mathrm{m}$} & \multicolumn{2}{|c|}{$45 \mu \mathrm{m}<\mathrm{BOS}<90 \mu \mathrm{m}$} \\
\hline & $\begin{array}{c}\text { XRD, } \\
\text { Rietveld }\end{array}$ & $\begin{array}{l}\text { XRF, } \\
\text { Bogue }\end{array}$ & $\begin{array}{c}\text { XRD, } \\
\text { Rietveld }\end{array}$ & $\begin{array}{l}\text { XRF, } \\
\text { Bogue }\end{array}$ & $\begin{array}{c}\text { XRD, } \\
\text { Rietveld }\end{array}$ & $\begin{array}{l}\text { XRF, } \\
\text { Bogue }\end{array}$ & $\begin{array}{c}\text { XRD, } \\
\text { Rietveld }\end{array}$ & $\begin{array}{l}\text { XRF, } \\
\text { Bogue }\end{array}$ \\
\hline $\mathrm{C}_{3} \mathrm{~S}\left(\mathrm{Ca}_{3} \mathrm{SiO}_{5}\right)$ & 70 & 54 & 56,40 & 29 & 74 & 60 & 69 & 60 \\
\hline $\mathrm{C}_{2} \mathrm{~S}\left(\mathrm{Ca}_{2} \mathrm{Sio}_{4}\right)$ & 10,23 & 13 & 28,17 & 37 & 10,3 & 12 & 14,7 & 8,5 \\
\hline $\mathrm{C}_{3} \mathrm{~A}\left(\mathrm{Ca}_{3} \mathrm{Al}_{2} \mathrm{O}_{6}\right)$ & 3,5 & 12 & 8,50 & 14 & 4,53 & 14,48 & 3.2 & 10 \\
\hline $\mathrm{C}_{4} \mathrm{AF}\left(\mathrm{Ca}_{4} \mathrm{Al}_{2} \mathrm{Fe}_{2} \mathrm{O}_{10}\right)$ & 11,72 & 13 & 6,52 & 13 & 11,52 & 12,21 & 12,5 & 12,5 \\
\hline
\end{tabular}

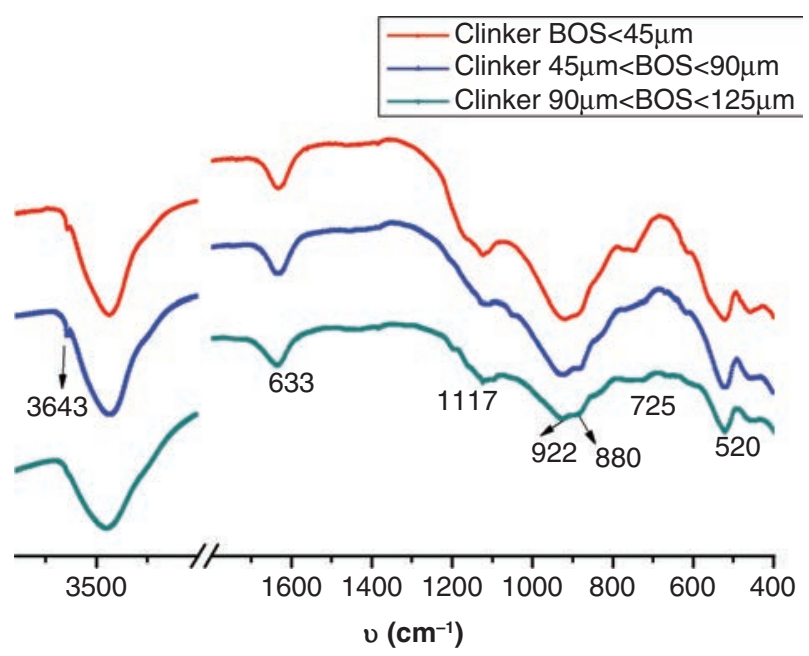

FIGURE 7. FTIR spectra for BOS clinkers.

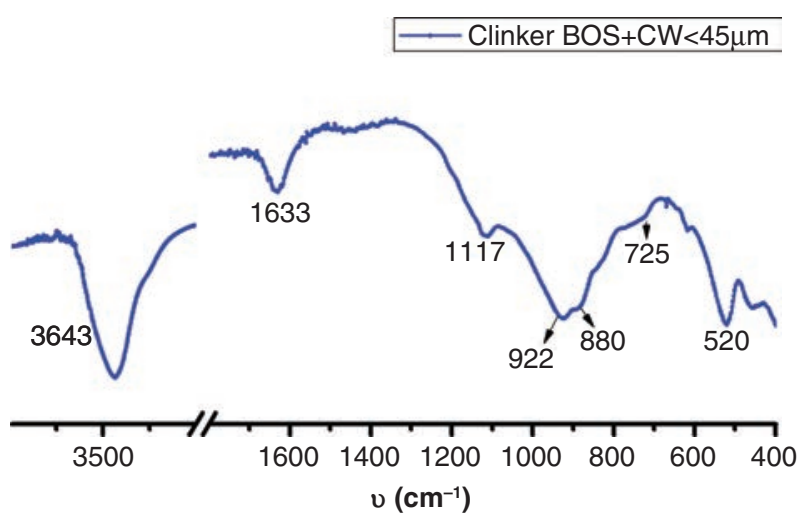

FIGURE 9. FTIR spectra for BOS+CW clinkers.

\subsection{Raw mix burnability}

The lime saturation factor (LSF), silica modulus $\left(\mathrm{M}_{\mathrm{S}}\right)$ and alumina modulus $\left(\mathrm{Al}_{2} \mathrm{O}_{3} / \mathrm{Fe}_{2} \mathrm{O}_{3}\right)$ for the clinkers studied are listed inTable 6. CW clinker burnability was unsuitable as a result of the high free lime content, which rose with particle size.

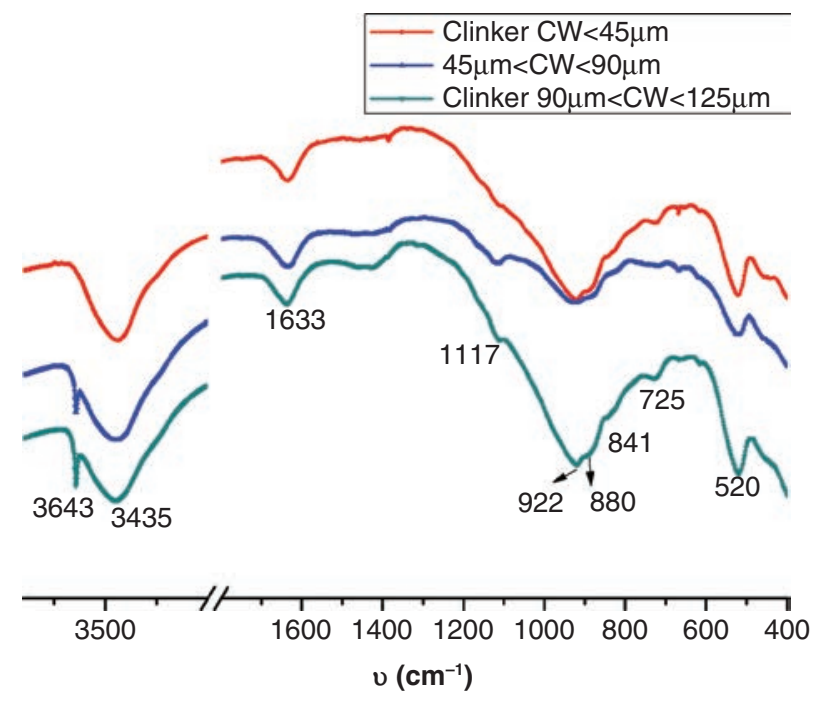

FIGURE 8. FTIR spectra for CW clinkers.

Whilst its LSF was a mere $90 \%$, clinker $\mathrm{CW}<45 \mu \mathrm{m}$ contained $2.68 \%$ free lime, denoting very poor burnability. The likewise high quartz content and an alumina modulus of around 1.9 were indications that $\mathrm{CW}$ molten phase viscosity and surface tension at $1400{ }^{\circ} \mathrm{C}$ were less suitable than in the other clinkers (19-20).

The free lime content also rose with particle size in the BOS clinkers. Further to the Fundal equation, after burning at $1400{ }^{\circ} \mathrm{C}$ for $30 \mathrm{~min}$, the free lime content of a cement depends on the chemistry, mineralogy and particle size of the reagents (12). The raw mixes studied had different and known LSF and alumina moduli, the diameter of their limestone particles was $<125 \mu \mathrm{m}$ and no sand was added to the mixes. The contribution of BOS and $\mathrm{CW}$ to the total free lime was consequently calculated by subtracting the chemical contribution of each from the free lime measured (Table 6). The inference drawn from the data in Table 6 was that $\operatorname{BOS}<45 \mu \mathrm{m}$, $45 \mu \mathrm{m}<\mathrm{BOS}<90 \mu \mathrm{m}$ and $\mathrm{BOS}+\mathrm{CW}<45 \mu \mathrm{m}$ would behave similarly during clinkerisation and deliver much higher quality raw mixes than any of the $\mathrm{CW}$ clinkers, including $\mathrm{CW}<45 \mu \mathrm{m}$. 


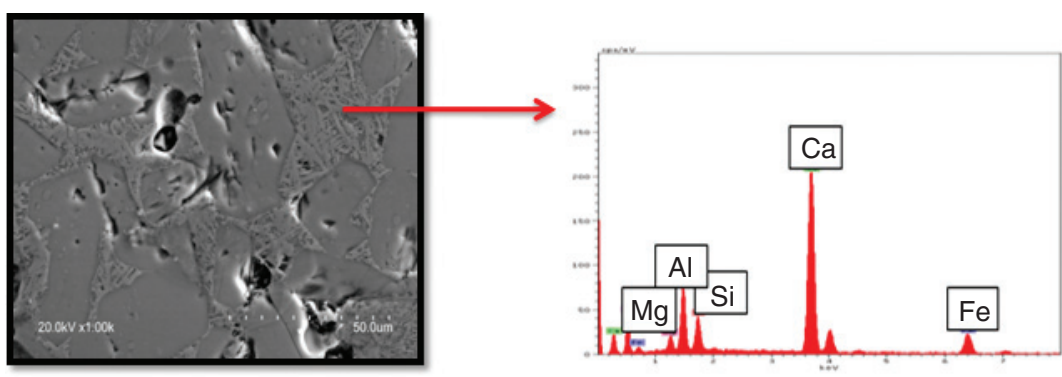

(a) BOS clinker $(X<45 \mu \mathrm{m})$

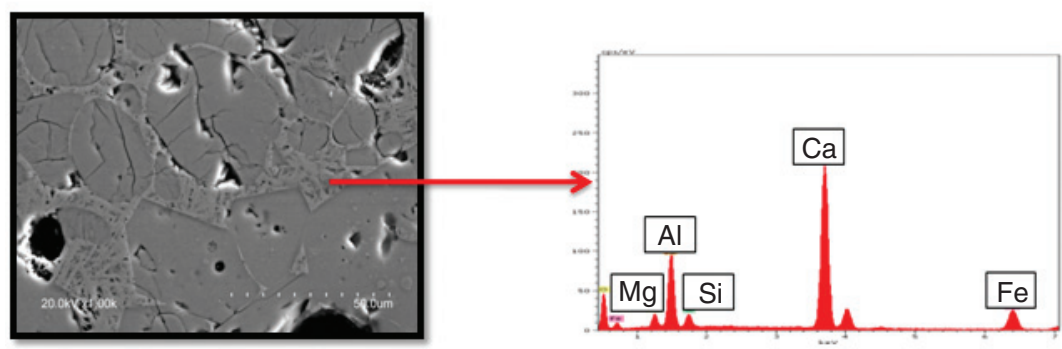

(b) BOS clinker $(<45 \mu \mathrm{m}<\mathrm{X}<90 \mu \mathrm{m})$

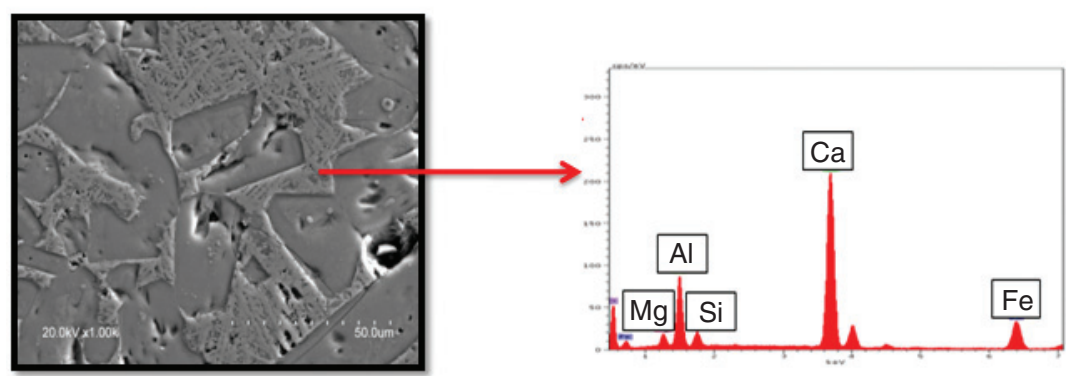

(c) Blended oil shale with coal waste clinker $(X<45 \mu \mathrm{m})$

FIGURE 10. SEM micrographs of clinkers and EDX findings for interstitial phase.

TABLE 5. EDX-based chemical analysis of BOS and CW clinker crystalline phases (wt $\%$ ) with particle size $<45 \mu \mathrm{m}$

\begin{tabular}{|c|c|c|c|c|c|c|c|c|c|}
\hline \multirow[b]{2}{*}{ Oxide } & \multicolumn{3}{|c|}{ Alite } & \multicolumn{3}{|c|}{ Belite } & \multicolumn{3}{|c|}{ Interstitial phase } \\
\hline & ClkBOS & Clk BOS+CW & Clk CW & Clk BOS & Clk BOS+CW & ClkCW & Clk BOS & Clk BOS+CW & ClkCW \\
\hline $\mathrm{SiO}_{2}$ & 16.5 & 21 & 15.7 & 20.2 & 22.63 & 19.9 & 6.8 & 3.6 & 2.1 \\
\hline $\mathrm{Al}_{2} \mathbf{O}_{3}$ & 1 & 1.2 & 0.5 & 1.7 & 1.02 & 1.4 & 14.5 & 19.5 & 16.2 \\
\hline $\mathrm{Fe}_{2} \mathrm{O}_{3}$ & 0.6 & 0.8 & 0.5 & 0.6 & 1.26 & 1 & 13.6 & 17.6 & 15.8 \\
\hline $\mathrm{SO}_{3}$ & 0 & 0 & 0 & 0.7 & 0.31 & 0 & 0 & 0.1 & 0 \\
\hline MgO & 1 & 1 & 0.1 & 0.6 & 0 & 0 & 3.6 & 2.4 & 1.6 \\
\hline $\mathbf{K}_{2} \mathrm{O}$ & 0 & 0 & 0 & 0.3 & 0.6 & 0.5 & 0 & 0.2 & 0.2 \\
\hline $\mathrm{CaO}$ & 66.3 & 76 & 62.9 & 57.7 & 73.12 & 54.7 & 48.8 & 56.5 & 40.6 \\
\hline
\end{tabular}

\section{CONCLUSIONS}

The present findings on the suitability of Moroccan oil shale and coal waste as raw materials in portland cement manufacture support the following conclusions.
- The main clinker phases in BOS, CW and $\mathrm{BOS}+\mathrm{CW}$ are alite, belite, aluminate and aluminium ferrite.

- Mixes containing oil shale deliver higher reactivity than coal waste materials, although 


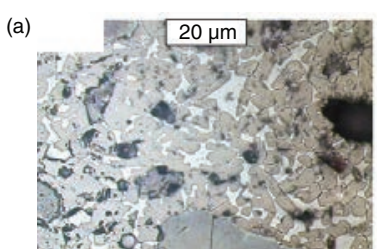

(c)

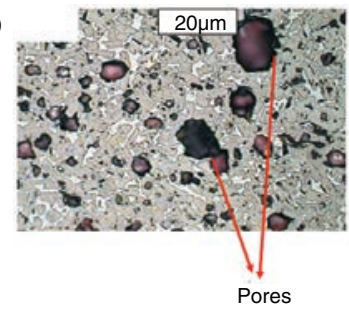

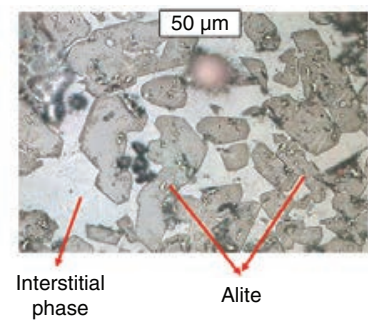

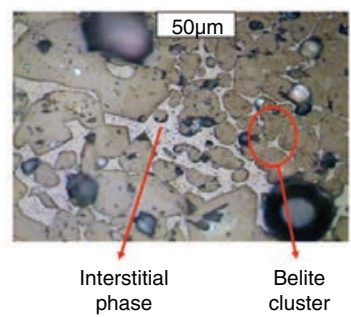

(b)

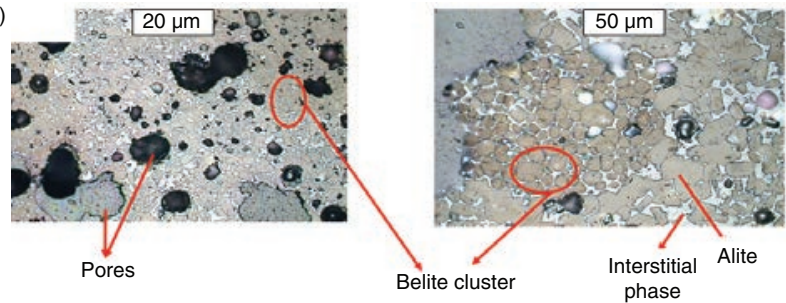

(d)
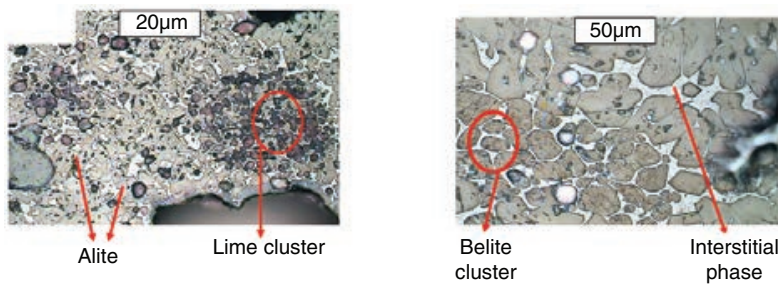

FIGURE 11. OM micrographs of: (a) BOS clinker, raw mix particle size <45 $4 \mathrm{~m}$; (b) CW clinker, raw mix particle size <45 $\mu$ m; (c) BOS clinker, raw mix particle size $90 \mu \mathrm{m}>\mathrm{BOS}>45 \mu \mathrm{m}$; (d) BOS+CW clinker, raw mix particle size $<45 \mu \mathrm{m}$.

TABLE 6. Lime saturation factor (LSF), silica modulus $\left(\mathrm{M}_{\mathrm{S}}\right)$, alumina modulus $\left(\mathrm{Al}_{2} \mathrm{O}_{3} / \mathrm{Fe}_{2} \mathrm{O}_{3}\right)$ and free lime in clinkers and Fundal model calculation of chemical and particle size contribution to free lime

\begin{tabular}{|c|c|c|c|c|c|c|}
\hline & LSF & $\mathrm{Al}_{2} \mathrm{O}_{3} / \mathrm{Fe}_{2} \mathrm{O}_{3}$ & $\mathbf{M}_{\mathrm{S}}$ & $\begin{array}{c}\text { Freelime } \\
\left(w_{t} \%\right)\end{array}$ & $\begin{array}{c}\text { Chemical } \\
\text { contribution to } \\
\text { free lime }\end{array}$ & $\begin{array}{l}\text { Particle size } \\
\text { contribution }\end{array}$ \\
\hline Clk-BOS $<45 \mu \mathrm{m}$ & 98 & 1.67 & 1.65 & 1.15 & -1.08 & 2.23 \\
\hline Clk-45 $\mu \mathrm{m}<$ BOS $<90 \mu \mathrm{m}$ & 103 & 1.62 & 1.9 & 2.78 & 1.27 & 1.51 \\
\hline Clk-90 $\mu \mathrm{m}<$ BOS $<125 \mu \mathrm{m}$ & 95 & 1.99 & 1.86 & 3.87 & -1.482 & 5.352 \\
\hline Clk-CW<45 $\mu \mathrm{m}$ & 90 & 1.92 & 1.7 & 2.68 & -3.58 & 6.26 \\
\hline Clk-45 $\mu \mathrm{m}<\mathrm{CW}<90 \mu \mathrm{m}$ & 98.7 & 2.2 & 1.5 & 6.39 & -1.269 & 7.659 \\
\hline Clk-90 $\mu \mathrm{m}<\mathrm{CW}<125 \mu \mathrm{m}$ & 95 & 1.99 & 1.75 & 19.53 & -1.79 & 21.32 \\
\hline Clk-BOS+CW $<45 \mu \mathrm{m}$ & 100 & 1.71 & 1.67 & 1.89 & -0.364 & 2.254 \\
\hline
\end{tabular}

reactivity is highest in the BOS raw mix with a particle size under $45 \mu \mathrm{m}$.

- Raw mixes containing oil shale and a blend of oil shale and coal waste exhibit good burnability when the particle size is $<90 \mu \mathrm{m}$, whereas burnability is poor in all the raw mixes containing coal waste, including the mix with particle size $<45 \mu \mathrm{m}$.

- Timahdit oil shale, alone or blended with Jerada coal waste, particularly where particle size is $<90 \mu \mathrm{m}$ in BOS and $<45 \mu \mathrm{m}$ in BOS $+\mathrm{CW}$, is apt for use as a raw material in lieu of clay and as a partial substitute for limestone in cement manufacture. The resulting low $\left(1400^{\circ} \mathrm{C}\right)$ clinkerisation temperature would afford both economic (lower energy and civil engineering costs) and environmental benefits.

\section{ACKNOWLEDGMENTS}

This paper has been carried out as part of a CSICMohammed V University of Rabat, cooperation programm (i-COOPA20067). Facilities given by IETcc
(CSIC) and funding from BIA 2013-47876-C2-1-P and BIA BIA2013-43293-R projects as well as the Regional Government of Madrid Community and European Social Fund (Geomaterials Programme2 S2013/MIT-2914) are gratefully acknowledged.

\section{REFERENCES}

1. Oss, H. G.; Padovani, A. C. (2002) Cement manufacture and the environment: part I: chemistry and technology. Ind. Ecol. 6 [1], 89-105. https://doi.org/ 10.1162/ 108819803766729212 .

2. Peake, S. (2001) Inside COP6: International Climate Change Negotiations. Refocus. 2 [1], 36-37.

3. Oss, H. G.; Padovani, A. C. (2003) Cement manufacture and the environment part II: environmental challenges and opportunities. Ind. Ecol. 7 [1], 93-126. https://doi. org/10.1162/108819803766729212.

4. Hilger, J. (2003) Combined utilization of oil shale energy and oil shale minerals within the production of cement and other hydraulic binders. Oil shale. 20 [3; SUPP], 347-355.

5. Bruan, V.; Halim, M.; Ziyad, M; Largeau, C.; Ambles, A. (2001) Characterization of the Moroccan Timahdit (X-layer) oil shale kerogen using pyrolysis and thermally assisted hydrolysis and methylation. Anal. Appl. 
Pyrolysis. $\quad 61[1-2], \quad 165-179 . \quad$ https://doi.org/10.1016/ S0165-2370(01)00131-0.

6. Darmane, Y.; Alaoui, A.; Kitane, S.; Bennajah, M.; Daramy, A.; Cherkaoui, M. (2009) Recycling the slagheap of an old coal mine (Morocco). Sep. Purif. Technol. 68[1], 125-128. https://doi.org/10.1016/j.seppur.2009.04.026.

7. Belkheiri, D.; Taibi, M.; Diouri, A.; Boukhari, A.; Aride, A.; Sassi, O. (2014) Characterization of Moroccan coal waste: valorization in the elaboration of the Portland clinker. MATEC Web of Conferences. 11, 01009. EDP Sciences. https://doi.org/10.1051/matecconf/20141101009.

8. EIA. (2012) Independent Statistics and Analysis. U.S. Energy Information and Administration <http://www.eia.gov/>.

9. Mounia, B.; Mostapha, B.; Rachid, H.; Hassan, B.; Abdelhakim, J.; Mohamed, S. (2013) Impact of mining wastes on groundwater quality in the province Jerada (eastern Morocco). Eng. Sci. Technol. 5 [8], 1601-1615.

10 Belkheiria, D.; Diouri, A.; Taibi, M.; Sassi, O.; Aride, J. (2015) Recycling of Moroccan coal gangue in the elaboration of a Portland clinker. Mater. Environ. Sci. 6 [6], 1570-1577.

11 Nabih, K.; Kada, M. K.; Hmiri, M.; Hamsi, N. (2014) Effects of the addition of oil shale ash and coal ash on physic-chemical properties of CPJ45 cement. In MATEC Web of Conferences. 11, 01012. EDP Sciences. https://doi. org/10.1051/matecconf/20141101012

12. FUNDAL, E. (1979) World Cement Technol. 10, (1979).

13. UNE 80243:2014. Cement test methods. Chemical analysis. Determination of free calcium oxyde. Ethylenglycol method.
14. Glasser, F.P. (1983) Reactions occurring during cement making. Structure and performance of cements, 70-75.

15. Kakali, G.;Parissakis, G.; Bouras, D. (1996) A study on the burnability and the phase formation of PC clinker containing Cu oxide. Cem. Concr. Res. 26 [10], 1473-1478. https:// doi.org/10.1016/0008-8846(96)00143-3.

16. Kakali, G.; Parissakis, G. (1995) Investigation of the effect of $\mathrm{Zn}$ oxide on the formation of Portland cement clinker. Cem. Concr. Res. 25 [1], 79-85. https://doi. org/10.1016/0008-8846(94)00115-F

17. Blanco-Varela, M. T. (1984) Reactivity of fly-ashes when they are used as constituent of Portland cement raw mixes. TIZ-Fachberichte. 108 [5], 304-307.

18. Moreno, T. V. (1975) Contribution to the study of the reactions of portland cement hydration by infrared spectroscopy, (1975).

19. Timashev, V.V. (1980) Cinétique de la clinkérisation. Structure et composition du clinker et ses phases. 7 th International Congress on the Chemistry of Cement. Paris. 1-19.

20. Butt,Y.M.; Timashev, V.V.; Osokin, A. P. (1974) The mechanism of clinker formation processes and the modification of its structure. The 6th International Congress on the Chemistry of Cement. Moscow. 2-43.

21. Puertas, F.; García-Díaz, I.; Barba, A.; Gazulla, M.F.; Palacios, M.; Gómez, M.P.; Martínez-Ramírez, S. (2008) Ceramic wastes as alternative raw materials for Portland cement clinker production. Cem. Concr. Comp. 9 [30], 798 80. https://doi.org/10.1016/j.cemconcomp.2008.06.003. 